\title{
KAJIAN KERAGAAN KARAKTERISTIK DAN TINGKAT PENGETAHUAN PETANI TENTANG SISTEM INTEGRASI SAPI DAN KELAPA SAWIT (SISKA) DI KECAMATAN PANGKALAN LESUNG, KABUPATEN PELALAWAN
}

\author{
Susy Edwina, Evy Maharani \\ Jurusan Agribisnis Fakultas Pertanian Universitas Riau \\ E-mail: sispa_27@yahoo.com
}

\begin{abstract}
Cattle development through regional integration system of oil palm plantations has a great opportunity to be developed. The idea of integration of beef cattle breeding business can overcome the problem of land scarcity. application of SISKA by Group Maju Bersama in the village of Bukit Harapan Siak has reached the stage of independence, but the number of farmers who have applied SISKA very limited. This is because the success of SISKA not only determined by the technology and the support of natural resources, but also by farmer characteristics. This study aims to determine the internal and external characteristics of farmers who implement systems integration; and the level of their knowledge of SISKA. This study uses a survey to determine Farmers Group Patient nrimo purposive. The qualitative descriptive data analysis using ordinal scale is Likert Scale. The results show the performance of the internal characteristics of farmers by age $90.91 \%$ are in the productive age farmers had high school education or equivalent $63.64 \%$, with an average tenure of 3 ha, number of dependents on average 4 persons, the average farm experience 18 years, kekosmopolitan including high category seen from the number of resources with a score of 4.18, searching for information with a score of 4.18 and 4.45 the motivation for information. The external characteristics of farmers as a whole are in the category of being seen from the intensity of the extension with a score of 4.12, the accuracy of the channel extension with a score of 3.80, the number of resources of 3.23, the price of the means of production with a score of 3 , the availability of low production with a score of 1,86, the environmental carrying capacity score of 3.95. The results of the study indicate the level of their knowledge of SISKA including high category.
\end{abstract}

Keywords : farmer characteristics, knowledge, SISKA, system integration

\begin{abstract}
Abstrak: Pengembangan ternak sapi melalui sistem integrasi di kawasan perkebunan kelapa sawit berpeluang besar untuk dikembangkan di daerah, mengingat potensi perkebunan kelapa sawit yang tersedia cukup luas terutama perkebunan rakyat. Gagasan integrasi usaha peternakan sapi potong ke dalam usaha perkebunan kelapa sawit dapat mengatasi masalah kelangkaan lahan yang menjadi sandungan obsesi capaian swasembada daging sapi dan kerbau. Hasil penelitian pendahuluan menunjukkan kinerja Kelompok Tani Maju Bersama yang menerapkan SISKA di Desa Bukit Harapan Kabupaten Siak sudah mencapai tahap kemandirian, namun dilihat dari petani yang menerapkan SISKA jumlahnya sangat terbatas karena keberhasilan SISKA tidak hanya ditentukan oleh kehandalan teknologi dan dukungan sumberdaya alam, tetapi juga oleh karakteristik petani. Penelitian ini bertujuan untuk mengetahui karakteristik internal dan eksternal petani yang menerapkan sistem
\end{abstract}


Susy Edwina, Evy M. : Kajian keragaan karakteristik dan tingkat pengetahuan petani...

integrasi; dan tingkat pengetahuan petani tentang SISKA. Kegiatan penelitian dilakukan sejak Bulan Mei tahun 2014 di Desa Mulya Subur Kecamatan Pangkalan Lesung Kabupaten Pelalawan Provinsi Riau. Penelitian ini menggunakan metode survei dengan penentuan Kelompok Tani Sabar Nrimo secara purposive, yang merupakan salah satu kelompok tani yang mendapatkan bantuan program SISKA dari Dinas Peternakan tahun 2011. Analisis data secara deskriptif kualitatif menggunakan skala ordinal yaitu Skala Likert. Hasil penelitian menunjukkan keragaan karakteristik internal petani berdasarkan umur $90,91 \%$ berada pada usia produktif, petani berpendidikan SLTA sederajat 63,64\%, dengan pemilikan lahan rata-rata 3 ha, jumlah tanggungan keluarga rata-rata 4 orang, pengalaman usahatani rata-rata 18 tahun, kekosmopolitan termasuk kategori tinggi dilihat dari jumlah sumber informasi dengan skor 4,18, mencari informasi dengan skor 4,18 dan motivasi mencari informasi 4,45. Karakteristik eksternal petani secara keseluruhan berada pada kategori sedang dilihat dari intensitas penyuluh dengan skor 4,12, ketepatan saluran penyuluhan dengan skor 3,80 , jumlah sumber informasi 3,23, harga sarana produksi dengan skor 3 , ketersediaan sarana produksi rendah dengan skor 1,86, daya dukung lingkungan skor 3,95. Selanjutnya hasil kajian menunjukkan tingkat pengetahuan petani tentang SISKA termasuk kategori tinggi, berdasarkan variabel kebutuhan yang dirasakan dari keberadaan SISKA, keinovatifan, serta kesesuaiannya dengan norma-norma dan sistem sosial.

Kata kunci: karakteristik petani, pengetahuan, SISKA, sistem integrasi

\section{PENDAHULUAN}

Sektor pertanian di Indonesia termasuk sub sektor perkebunan sebagai salah satu bidang usaha yang berbasis sumberdaya alam (natural resource based) berpeluang besar untuk berkembang menjadi bidang usaha andalan nasional. Hal ini antara lain dikarenakan secara alamiah Indonesia diberi karunia berupa keunggulan komparatif (comparative advantage) dalam memproduksi komoditas unggulan perkebunan wilayah tropis yang berpeluang kuat untuk ditingkatkan daya saingnya (Daryanto, 2007).

Sejak revitalisasi pertanian peternakan dan kehutanan (RPPK) diluncurkan Presiden RI pada 2005, konsep integrasi sawit sapi mulai diadopsi dan memasuki 2007, beberapa pemerintah daerah menjadikannya sebagai program unggulan. Keterbatasan sumber pakan konvensional, dapat diatasi dengan menggunakan bahan pakan berbasis limbah pertanian dan industri pertanian dengan mengembangkan sistem pertanian terintegrasi tanaman ternak. Permasalahannya adalah integrasi tanaman ternak masih terbatas pada skala kecil yang dilakukan oleh peternakan rakyat. Integrasi usaha tanaman perkebunan dan ternak sapi masih terbatas. Padahal potensi limbah untuk pakan mampu meningkatkan populasi sapi potong cukup besar. Keterlibatan perusahaan perkebunan dalam pengembangan sistem pertanian integrasi tanaman ternak dapat mengefisienkan proses produksi dan meningkatkan daya saing daging sapi lokal.Pengembangan SISKA membutuhkan dukungan dan kesiapan semua pihak, sehingga terjadi optimalisasi pemanfaatan lahan dan pemberdayaan petani yang mengarah kepada efisiensi biaya dan pemanfaatan limbah spesifik lokasi.

Sistem integrasi tanaman ternak sapi potong sebagai salah satu upaya untuk meningkatkan produksi sapi potong yang merupakan penyumbang daging terbesar terhadap produksi daging nasional sehingga usaha ternak ini berpotensi untuk dikembangkan sebagai usaha yang menguntungkan dan meningkatkan pendapatan peternak. Penerapan sistem integrasi sapi dengan memanfaatkan tanaman dan limbah agroindustri merupakan upaya pemecahannya dengan memanfaatkan ternak ternak sapi sebagai pabrik hidup yang memanfaatkan tanaman dan limbah agroindustri sebagai pakan, sekaligus pabrik penghasil pupuk organik. Integrasi tanaman ternak merupakan suatu sistem pertanian yang dicirikan oleh keterkaitan yang erat antara komponen tanaman dan ternak dalam suatu usahatani atau dalam 
suatu wilayah. Keterkaitan tersebut merupakan suatu faktor pemicu dalam mendorong pertumbuhan pendapatan masyarakat tani dan pertumbuhan eknomi wilayah dengan cara yang berlanjut. Ciri keterkaitan antara lain adalah penggunaan sumberdaya yang beragam seperti tanaman hijauan dan limbah agroindustri. Model sistem integrasi tanaman ternak sapi merupakan salah satu bentuk optimalisasi pemanfaatan sumberdaya lahan dalam upaya meningkatkan pendapatan petani.

Usaha pengembangan integrasi sawit sapi memiliki tujuan ganda yaitu menyediakan ternak sapi siap potong melalui unit usaha penggemukan (fattening) dan ternak sapi bibit sebar melalui unit usaha pembibitan (breeding) serta beberapa tujuan lain, yaitu a) memanfaatkan limbah perkebunan kelapa sawit terutama pelepah sawit, sebagai sumber pakan ternak sapi potong, b) menyediakan pupuk organik padat berupa limbah usaha ternak sapi potong guna memenuhi kebutuhan pupuk tanaman kelapa sawit, c) menyediakan kesempatan kerja bagi masyarakat sekitar lokasi pengembangan usaha integrasi sawit sapi, dan d) membantu pemerintah daerah setempat dalam penyediaan daging ternak sapi potong (Novra, 2012).

Sistem Integrasi Sapi Kelapa Sawit (SISKA) mulai diperkenalkan di Kabupaten Pelalawan pada tahun 2007. Memasuki awal tahun 2009, integrasi sapi dan kelapa sawit menjadi salah satu program unggulan Kabupaten Pelalawan. Pemerintah Kabupaten Pelalawan memiliki harapan besar dengan adanya SISKA, dimana petani tidak kesulitan lagi mencari pakan rumput untuk ternak sapi mereka seperti yang selama ini sering menjadi keluhan petani. Dinas peternakan Kabupaten Pelalawan mencatat, sampai pertengahan tahun 2014 terdapat 22 lokasi yang mendapat bantuan mesin pencacah (cooper) pelepah kelapa sawit untuk mendukung pelaksanaan SISKA. Kelompok tani yang mendapat bantuan mesin tersebut secara umum memiliki kecenderungan yang baik untuk menjalankan sistem integrasi ini. Terdapat sekitar 15 lokasi yang berhasil melaksanakan SISKA bahkan ada beberapa lokasi yang memanfaatkan limbah kotoran sapi sebagai sumber biogas sehingga menjadi Desa Mandiri Energi Terbarukan (Desa MET). Lokasi lain yang mendapatkan bantuan mesin untuk melaksanakan SISKA namun saat ini tidak menjalankan lagi mayoritas terkendala pada kurangnya ketersediaan bahan pendukung untuk pengolahan pakan sapi dari pelepah kelapa sawit. Sebanyak 15 lokasi yang berhasil menjalankan SISKA tersebar di 4 kecamatan di Kabupaten Pelalawan. Terdapat 7 lokasi yang berhasil menjalankan SISKA di Kecamatan Pangkalan Lesung.

Integrasi antara sapi dan kelapa sawit di Kabupaten Pelalawan secara umum berjalan dengan baik. Banyak lokasi yang merasa sangat terbantu dengan kehadiran inovasi ini. Mesin pencacah (cooper) sebagai sebuah inovasi pada integrasi ini sangat meringankan beban petani yang selama ini sulit mencari rumput untuk pakan sapi. Petani dapat melakukan pengolahan pelepah disekitar kandang sapi yang ada pada perkebunan mereka. Mayoritas petani kelapa sawit didaerah yang menjalankan integrasi ini dapat meningkatkan kesejahteraan dan perekonomian mereka.

Pelaksanaan Sistem Integrasi Sapi Kelapa Sawit sebenarnya dapat memberikan dampak positif bagi petani kelapa sawit untuk meningkatkan pendapatan. Faktanya di Kabupaten Pelalawan belum semua lokasi dapat memaksimalkan bantuan mesin pencacah pelepah kelapa sawit. Masih ada beberapa lokasi yang belum maksimal menjalankan sistem integrasi ini yang mayoritas dikarenakan sulitnya memperoleh bahan campuran. Tujuan penelitian ini adalah untuk mengetahui keragaan karakteristik internal dan eksternal petani yang menerapkan sistem integrasi dan tingkat pengetahuan petani tentang SISKA.

\section{METODE PENELITIAN}

Kegiatan penelitian dilakukan sejak Bulan Mei tahun 2014 di Desa Mulya Subur Kecamatan Pangkalan Lesung Kabupaten Pelalawan Provinsi Riau. Penelitian ini menggunakan metode survei dengan penentuan Kelompok Tani Sabar Nrimo secara purposive, yang merupakan salah satu dari kelompok tani yang mendapatkan bantuan program SISKA dari Dinas Peternakan tahun 2011. Metode pengambilan sampel dalam penelitian ini dilakukan secara sensus, yaitu untuk petani yang masih menjalankan SISKA (Kelompok Tani Sabar Nrimo Desa Mulya Subur sebanyak 11 orang petani). 
Susy Edwina, Evy M. : Kajian keragaan karakteristik dan tingkat pengetahuan petani...

Data yang dikumpulkan meliputi data primer: 1) karakteristik internal petani berupa: umur, pendidikan, jumlah tanggungan keluarga, lama pengalaman berusahatani, penguasaan lahan dan kekosmopolitan; 2) Karakteristik eksternal petani berupa: intensitas penyuluh, ketepatan saluran penyuluhan, jumlah sumber informasi, keterjangkauan harga sarana produksi, dan ketersediaan sarana produksi; 3) Pengetahuan petani terhadap SISKA meliputi: pengetahuan tentang praktek-praktek sebelumnya tentang SISKA, kebutuhan yang dirasakan oleh petani terhadap SISKA, keinovatifan SISKA, serta norma dari sistem sosial petani terhadap SISKA. Data sekunder diperoleh dari kantor Kabupaten, kantor Kecamatan, dan instansi yang terkait.

Analisis data dilakukan secara deskriptif dan analisa statistik non parametrik, dengan cara membuat tabulasi distribusi responden dari setiap variabel yang diteliti. Untuk mendeskripsikan karakteristik internal dan eksternal petani dan variabel pengetahuan petani terhadap SISKA, digunakan skala ordinal yaitu dengan berpedoman pada Skala Likert, dimana setiap jawaban diberi skor. Pokok-pokok skala menggunakan skor berkisar antara 1-5, dari total nilai pokok-pokok skala tersebut dikelompokkan menjadi 5 kategori. Untuk menentukan kategori jawaban tersebut dilakukan dengan menggunakan rumus:

Skor variabel $=\underline{\text { Jumlah Pertanyaan } \mathrm{x} \text { Skala Skor }}$ Jumlah Pertanyaan

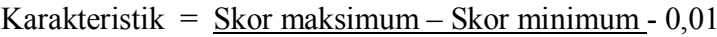
Pengetahuan $\frac{\text { Jumlah Kategori }}{\text { data }}$

Analisis data karakteristik dan pengetahuan petani kelapa sawit terhadap SISKA secara keseluruhan yaitu : jumlah pertanyaan, skor tertinggi (5), skor terendah (1), maka perhitungannya adalah:

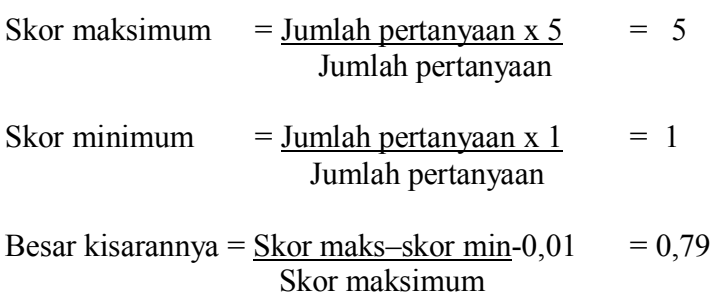

Berdasarkan perhitungan diatas, maka secara keseluruhan adopsi inovasi petani kelapa sawit terhadap SISKA di Kabupaten Pelalawan dibagi menjadi 5 kategori, dapat dilihat pada Tabel 1 .

Tabel 1. Perhitungan Kategori Jawaban Skor

\begin{tabular}{lc}
\hline \multicolumn{1}{c}{ Kategori } & Skor \\
\hline Sangat Rendah (SR) & $1,00-1,79$ \\
Rendah (R) & $1,80-2,59$ \\
Sedang (S) & $2,60-3,39$ \\
Tinggi (T) & $3,40-4,19$ \\
Sangat Tinggi (ST) & $4,20-5,00$ \\
\hline
\end{tabular}

Sumber data : Data Diolah

\section{HASIL DAN PEMBAHASAN}

\section{Profil Kelompok Tani}

Kelompok tani Sabar Nrimo berada di Desa Mulya Subur (SP7) Kecamatan Pangkalan Lesung Kabupaten Pelalawan. Sistem Integrasi Sapi Kelapa Sawit (SISKA) sangat memberi dampak positif bagi Kelompok Tani Sabar Nrimo, Desa Mulya Subur, Kecamatan Pangkalan Lesung, Kabupaten Pelalawan. Kelompok tani yang diketuai Bapak Podo Sunatmo ini melakukan pengolahan pelepah kelapa sawit menjadi pakan sapi setiap harinya. Sejak menerapkan SISKA pada tahun 2011 melalui bantuan mesin cooper dari Dinas Peternakan Kabupaten Pelalawan, kelompok tani ini merasakan perubahan besar terhadap pendapatan dan kesejahteraan mereka.

Kelompok Tani Sabar Nrimo sangat terbantu dengan adanya inovasi pada Sistem Integrasi Sapi Kelapa Sawit (SISKA). Inovasi seperti kehadiran mesin pencacah pelepah kelapa sawit/cooper sangat membantu petani. Kelompok tani ini memiliki satu mesin cooper yang dioperasikan setiap harinya. Sebelumnya peternak sapi sangat kesulitan mencari rumput untuk pakan sapi mereka. Bahkan peternak sapi sampai mencari rumput ke daerah Langgam yang jaraknya sekitar 2 jam perjalanan dari Desa Mulya Subur. Melaksanakan SISKA membuat petani kini tidak kesulitan lagi terhadap ketersediaan pakan sapi, karena potensi pelepah sangat banyak di daerah ini.

Sistem Integrasi telah membantu memecahkan permasalahan pakan yang selama ini dialami petani peternak dengan memanfaatkan pelepah kelapa sawit. Bahkan kelompok tani sudah memanfaatkan kotoran ternak menjadi biogas. 


\section{Karakteristik Internal}

Karakteristik internal berkaitan dengan segala sesuatu yang berkaitan dengan kondisi yang ada pada petani sebagai pelaku usaha. Biasanya karakteristik petani erat kaitannya dengan kemampuan pettani untuk menerima atau mengadopsi teknologi baru (Maharani, 2001). Keadaan sosial ekonomi petani merupakan gambaran secara garis besar dari petani baik umur, pendidikan, pengalaman usahatani, tanggungan keluarga, luas lahan dan lainnya. Adapun keragaan karakteristik internal petani di Desa Mulya Subur seperti dalam Tabel 2. Maharani (2001) umur petani dapat mempengaruhi kegiatan usahataninya, dengan umur yang lebih matang mereka cenderung lebih cepat menerima inovasi baru dan berbagai informasi yang berkaitan dengan perkembangan usahataninya baik informasi teknologi maupun informasi yang berkaitan dengan harga dalam tawar menawar petani dengan pedagang. Tabel 2 menunjukkan karakteristik internal dilihat dari umur mayoritas petani berada pada umur yang produktif 90,91 persen. Kondisi ini memudahkan bagi petani tentunya dalam mengadopsi dan merespon hal-hal baru yang diperolehnya sehingga dapat membangun dan mengembangkan usaha yang dijalankannya. Jumlah tanggungan keluarga petani rata-rata 4 orang. Jumlah tanggungan keluarga akan mempengaruhi petani dalam memperoleh pendapatan usahataninya. Bila dilihat dari pengalaman usahatani petani rata-rata 18 tahun. Lamanya berusahatani merupakan pengalaman bagi petani yang mencerminkan kegiatan dan ketrampilan dalam mengelola usahataninya. Dengan pengalaman yang cukup petani lebih mampu dan matang mempertimbangkan dalam setiap langkah keputusannya baik kegiatan usahataninya maupun pemasaran hasil. Pendidikan petani di Desa Mulya Subur bisa dikatakan sudah baik dimana 63,64 persen berpendidikan SLTA. Menurut Herijanto (1991) pendidikan merupakan salah satu penentu dalam meningkatkan dan mengembangkan usaha. Apalagi dalam pembangunan pertanian pendidikan merupakan salah satu syarat pelancar karena dengan pendidikan dapat meningkatkan produktivitas petani.

Luas lahan merupakan salah satu faktor produksi penting dalam usahatani. Besar kecilnya lahan mempengaruhi besar kecilnya pendapatan yang diperoleh dari usahatani. Berdasarkan Tabel 2 luas lahan petani tergolong luas dengan rata-rata 3 ha dan memungkinkan bagi petani untuk dapat berusahatani kelapa sawit dengan lebih baik sehingga produksi yang dicapai tinggi yang secara langsung mempengaruhi terhadap pendapatan yang diterimanya. Kondisi ini menjadi potensi yang sangat baik untuk ketersediaan pelepah kelapa sawit yang menjadi bahan utama pengolahan pakan ternak sapi. Dengan melaksanakan SISKA pendapatan dari ternak sapi yang mereka usahakan bersamaan dengan kebun sawit yang memberi peluang untuk memperoleh pendapatan ganda.

Kekosmopolitan merupakan tingkat kemampuan seseorang dalam mencari informasi pengetahuan berupa pengalaman melihat, mendengar, membaca serta bepergian ke suatu tempat sehingga dapat menambah pengalaman dalam memecahkan masalah dan perubahan perilaku individunya. Kekosmopolitan petani untuk Desa Mulya Subur termasuk tinggi dengan rata-rata skor

Tabel 2. Karakteristik Internal Petani di Desa Mulya Subur

\begin{tabular}{llc}
\hline No & \multicolumn{1}{c}{ Karakteristik Internal } & Nilai \\
\hline 1. & Umur petani berada pada usia produktif (persen) & 90,91 \\
2. & Jumlah tanggungan keluarga rata-rata (orang) & 4 \\
3. & Pengalaman usahatani kelapa sawit bervariasi (tahun) & 18 \\
4. & Pendidikan petani SLTA (persen) & 63,64 \\
5. & Luas lahan rata-rata (ha) & 3 \\
6. & Kekosmopolitan & 4,18 \\
& a. Jumlah sumber informasi tinggi (skor) & 4,18 \\
& b. Kemampuan dalam mencari informasi tinggi (skor) & 4,45 \\
\hline
\end{tabular}

Sumber data : Analisis data primer 
4,27, dilihat dari jumlah informasi dikelompok tani Sabar Nrimo termasuk tinggi dengan skor 4,18. Jumlah sumber informasi termasuk tersedia dan membuat petani tidak sulit untuk melaksanakan SISKA. Begitu juga dengan kemampuan dan motivasi dalam mencari informasi juga tinggi. Hasil penelitian ini menunjukkan bahwa petani sebenarnya sudah kosmopolit namun dalam pelaksanaan SISKA kendala utama yaitu keterbatasan dalam memperoleh bahan campuran untuk mengolah pelepah menjadi pakan. Namun petani memanfaatkan bahan campuran yang ada untuk tetap mengolah pelepah menjadi pakan seperti solid, ampas tahu. Inovasi tetap dilakukan petani dengan keterbatasan bahan campuran yang ada.

\section{Karakteristik Eksternal}

Karakteristik eksternal dalam penelitian ini berkaitan dengan kondisi luar yang mempengaruhi petani dalam melaksanakan kegiatan usahataninya. Adapun karakteristik eksternal yang ada pada petani di Desa Mulya Subur dapat dilihat pada Tabel 3. Berdasarkan rata-rata skor yang diperoleh di Desa Mulya Subur intensitas penyuluh sebesar 4,12 termasuk kategori tinggi. Kondisi ini menunjukan bahwa penyuluh pertanian di Kabupaten Pelalawan telah melaksanakan perannya dengan baik. Penyuluh selalu datang melakukan penyuluhan dan memberikan informasi tentang SISKA bagi petani.

Petani sampel penelitian merasa sangat terbantu dengan keberadaan penyuluh dan mengaku sangat mudah menemui penyuluh jika memerlukan bantuan. Selain penyuluh ada juga dinas yang terkait yang melakukan penyuluhan seperti Dinas Perkebunan dan Dinas Peternakan Kabupaten Pelalawan.

Ketepatan saluran penyuluh di Desa Mulya Subur sebesar 3,80, menunjukkan ketepatan saluran penyuluhan dikategorikan tinggi. Kondisi ini menunjukkan petani mendapatkan informasi tentang SISKA yang tinggi dari penyuluh, cukupnya ketersediaan sumber informasi, dan kegiatan penyuluhan yang tersedia. Ketepatan saluran penyuluhan sangat diharapkan oleh petani yang ada di Kabupaten Pelalawan, untuk mendapatkan informasi dari penyuluh atau dari pusat informasi. Jumlah sumber informasi yang diperoleh petani kelapa sawit rakyat di Desa Mulya Subur terhadap SISKA dengan skor rata-rata 3,23 termasuk kategori sedang. Kondisi ini menunjukkan petani yang mendapatkan informasi terbaru tentang SISKA bisa dikatakan cukup tersedia. Kondisi ini sejalan dengan intensitas penyuluh dan ketepatan saluran penyuluhan yang memiliki kategori tinggi. Petani cukup mudah mendapatkan informasi terbaru baik dari penyuluh, pengalaman petani lain, juga dari media massa dan elektronik.

Tabel 3. Karakteristik Eksternal Petani di Desa Mulya Subur

\begin{tabular}{clc}
\hline No & \multicolumn{1}{c}{ Karakteristik Eksternal } & Skor \\
\hline 1. & Intensitas Penyuluh tinggi & 4,12 \\
2. & Ketepatan saluran penyuluh tinggi & 3,80 \\
3. & Jumlah sumber informasi sedang & 3,23 \\
4. & Keterjangkauan harga saprodi sedang & 3 \\
5. & Ketersediaan saprodi rendah & 1,86 \\
6. & Daya dukung lingkungan tinggi & 3,95
\end{tabular}

Sumber data : Analisis data primer

Tabel 4. Pengetahuan Petani Kelapa Sawit Terhadap Inovasi SISKA

\begin{tabular}{llcc}
\hline No & \multicolumn{1}{c}{ Uraian } & Skor & Kategori \\
\hline 1 & Praktek sebelumnya & 3,64 & Tinggi \\
2 & Kebutuhan yang dirasakan & 4,23 & Tinggi \\
3 & Keinovatifan & 4,36 & Tinggi \\
4 & Norma-norma dan sistem sosial & 3,50 & Tinggi \\
\hline
\end{tabular}

Sumber data : Analisis data primer 
Susy Edwina, Evy M. : Kajian keragaan karakteristik dan tingkat pengetahuan petani...

Keterjangkauan harga saprodi merupakan seberapa mampu petani dalam membeli saprodi, kita ketahui pada saat sekarang ini harga-harga saprodi semakin mahal sehingga banyak petani yang tidak sanggup untuk membeli saprodi untuk menunjang kegiatan usahatani. Keterjangkauan harga saprodi merupakan seberapa mampu petani dalam membeli saprodi, kita ketahui pada saat sekarang ini harga-harga saprodi semakin mahal sehingga banyak petani yang tidak sanggup untuk membeli saprodi untuk menunjang kegiatan usahatani. Rata-rata skor di Desa Mulya Subur sebesar 3 termasuk dalam kategori sedang, karena beberapa petani merasa mampu dalam membeli saprodi untuk pelaksanaan SISKA dan sebagian lagi masih merasa harga saprodi mahal dan belum terjangkau oleh petani. Sehingga petani ratarata melakukan pengolahan pelepah kelapa menggunakan campuran berupa dedak, gula, garam dan amapas tahu yang dianggap harganya masih terjangkau. Sementara untuk mendapatkan bungkil sebagai bahan campuran harganya sangat mahal dan sulit didapatkan.

Rata-rata skor ketersediaan saprodi untuk pelaksanaan SISKA di Desa Mulya Subur diperoleh skor 1,86 termasuk kategori rendah. Hal ini menunjukkan ketersediaan saprodi di Desa Mulya Subur kurang tersedia dan sedikit pihak yang memfasilitasinya. Kondisi ini disebabkan potensi wilayah Kabupaten Pelalawan merupakan daerah pertanian dan Perusahaan Kelapa Sawit tetapi perusahaan tersebut tidak menjual solid dan bungkil sawit sebagai bahan campuran pembuatan pakan sapi dari pelepah sawit kepada petani sehingga kurang tersedianya dalam mendapatkan saprodi.

Daya dukung lingkungan akan mendukung pelaksanaan program SISKA yang dijalankan petani. Ketersediaan sumberdaya yang diperlukan dalam proses pelaksanaan program akan membuat inovasi lebih mudah diterima petani ternak. SISKA pada dasarnya adalah program yang ramah lingkungan dengan pola saling menguntungkan antara perpaduan ternak sapi dan perkebunan kelapa sawit. Ratarata skor daya dukung lingkungan di Desa Mulya Subur 3,95 termasuk kategori tinggi. Hal ini menunjukkan sangat tepat program SISKA dikembangkan di Desa Mulya Subur apabila dilihat dari daya dukung lingkungan.

\section{Pengetahuan Petani}

Berdasarkan teori Rogers (1983) yang membahas tentang teori proses keputusan inovasi, pengetahuan dapat dibagi menjadi 4 kriteria, diantaranya adalah; 1) Praktek-praktek sebelumnya; 2) Kebutuhan yang dirasakan; 3) Keinovatifan; 4) Norma-norma dari sistem sosial. Pengetahuan petani terhadap SISKA di Desa Mulya Subur termasuk kategori tinggi. Kondisi ini menunjukkan petani memiliki pengetahuan yang sangat baik terhadap inovasi SISKA. Petani di Desa Mulya Subur sangat membutuhkan inovasi untuk mengatasi permasalahan pakan. SISKA menjadi solusi tepat dan sangat inovatif untuk mengatasi permasalahan tersebut. Pengetahuan petani terhadap SISKA sudah sangat baik dan menganggap SISKA sudah sesuai dengan adat istiadat dan norma yang berlaku. Namun, praktek-praktek terdahulu tentang pelaksanaan SISKA masih dirasakan kurang oleh petani, sehingga keberadaan penyuluh diharapkan dapat membantu petani dalam menyelesaikan persoalan yang dihadapi. Rata-rata skor pada tahap pengetahuan petani tentang praktekpraktek sebelumnya sebesar 3,64 termasuk kategori tinggi. Hal ini dikarenakan pelatihan dan pembinaan dibantu oleh penyuluh dan dinas-dinas terkait. Kebutuhan yang dirasakan oleh petani terhadap program SISKA untuk dapat meningkatkan pendapatan, kesejahteraan dan produksi kelapa sawit yang dimiliki oleh petani. Program SISKA juga dibutuhkan petani untuk dapat memenuhi pakan ternak sapi. Ratarata skor untuk kebutuhan yang dirasakan dengan skor 4,23 termasuk kategori tinggi. Kebutuhan yang dirasakan oleh petani terhadap SISKA dapat memberikan manfaat yang besar bagi petani. Petani selama ini sering kesulitan mencari pakan rumput dengan kehadiran SISKA ini merupakan suatu inovasi yang sangat bermanfaat bagi petani. Petani menyadari bahwa SISKA diharapkan mampu memberikan perbaikan kesejahteraan rumahtangga petani melalui peningkatan produksi sehingga dapat meningkatkan pendapatan.

Suatu inovasi akan mudah diadopsi apabila menguntungkan bagi calon adopternya. Begitu juga inovasi teknologi pengolahan pakan sapi dari pelepah sawit yang merupakan sebuah inovasi tentunya akan lebih mudah 
diadopsi apabila dapat memberikan keuntungan bagi calon adopternya. Hasil penelitian menunjukkan rata-rata skor yang menjelaskan keinovatifan sebesar 4,36 termasuk kategori tinggi karena petani merasakan kegunaan dan manfaat dari hasil pelaksanaan SISKA yang sudah dilakukan. Secara umum setiap kelompok tani yang melaksanakan SISKA dapat menerima inovasi ini dengan baik. Kondisi ekonomi setiap anggota dapat meningkat dan petani ternak tidak kesulitan lagi untuk memenuhi kebutuhan pakan ternak sapi mereka. Inovasi pengolahan pelepah menjadi solusi baru bagi petani dan sangat membantu petani dengan kehadiran mesin pencacah (cooper) pelepah kelapa sawit.

Norma-norma dan sistem sosial merupakan semua petani yang mempermasalahkan atau tidak mempermasalahkan adanya inovasi pengolahan pelepah sawit. Norma-norma dan sistem sosial di Desa Mulya Subur termasuk kategori tinggi dengan skor 3,50.

\section{KESIMPULAN}

1. Karakteristik petani dalam menerapkan SISKA di Desa Mulya Subur dilihat dari kriteria umur petani berada pada usia produktif, tingkat pendidikan mayoritas petani SMA, jumlah tanggungan keluarga mayoritas 4 orang, lama pengalaman usahatani mayoritas kebanyakan sudah sangat berpengalaman lebih dari 15 tahun, luas lahan petani mayoritas $3 \mathrm{Ha}$, tingkat kekosmopolitan petani kelapa sawit di Desa Mulya Subur tergolong tinggi.
2. Karakteristik eksternal petani dilihat dari intensitas penyuluh, ketepatan saluran penyuluh, jumlah sumber informasi, keterjangkauan harga saprodi dan ketersedian saprodi termasuk kategori sedang.

3. Tingkat pengetahuan petani tentang SISKA termasuk kategori tinggi, berdasarkan variabel kebutuhan yang dirasakan dari keberadaan SISKA, keinovatifan, serta kesesuaiannya dengan norma-norma dan sistem sosial.

\section{DAFTAR PUSTAKA}

Daryanto, Arief. 2007. Peranan dan Pengembangan Hortikultura Melalui Pendekatan Cluster dan Contract Farming. Prosiding Konperensi Nasional Ke XV Perhimpunan Ekonomi Pertanian Indonesia (PERHEPI). Diselenggarakan di Hotel Sahid Raya Surakarta tanggal 34 Agustus 2007.

Herijanto, 1991. Sumberdaya Manusia. Penerbit Erlangga, Jakarta.

Maharani, Evy, 2001. Analisis Pemasaran Jeruk Siam dan Faktor-faktor yang Mempengaruhi Posisi Tawar Menawar Petani di Kabupaten Kampar. Tesis Pascasarjana Universitas Padjadjaran Bandung.

Novra. 2012. PTPN VI, Integrasi Sawit Sapi. Www. Academia.edu. Akses 18 Oktober 2014.

Rogers, E.M. 1983. Diffusions of Innovations, Third Edition. Free Press. New York. 